\title{
FEATURES OF THE FUNCTIONING OF ORGANISM ENERGY SUBSYSTEM BY INDICATORS OF CARDIOVASCULAR SYSTEM AMONG INDIVIDYALS PRONE AND RESISTANT TO DEVELOPMENT OF THE MONOTONY STATE
}

\author{
Kalnysh V., Pyshnov G., Opanasenko V., Ogryzkov A.

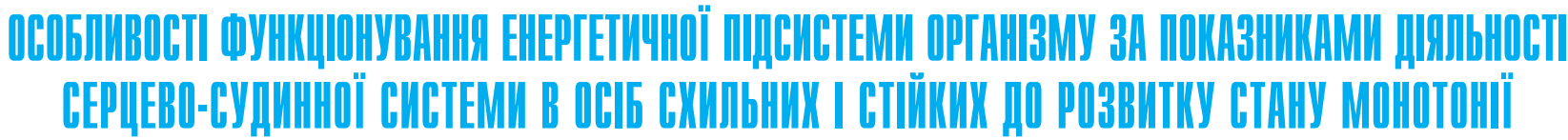

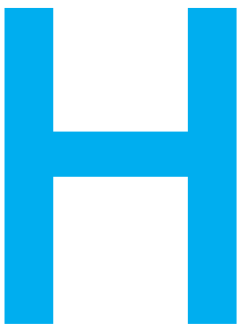

ині існує багато одноманітних видів робіт, пов'язаних $з$ операторською діяльністю, які сприяють розвиткові стану монотонії у працівників [1]. Проблема дослідження цього стану $е$ досить актуальною для сучасних видів праці, важливими рисами яких є функції спостереження, управління і контролю в умовах надходження невеликої кількості інформації, значного часу спостереження, обмеженої рухово активності [2, 3]. За даними вітчизняних та зарубіжних фахівців, значна кількість аварійних ситуацій та відмов техніки під час управління складними технічними системами відбувається внаслідок помилок персоналу, формування яких пов'язане з психофізіологічними особливостями і емоційним станом працівників, що виконують одноманітну роботу $[4,5]$. Так, за літературними даними, 80\% усіх аварій на флоті відбувається через помилки людини, а на транспорті цей показник наближається до 90\% випадків [6].

Вплив фактора одноманітності на працездатність людини має чітко індивідуальний характер. Так, у літературі [7] показано, що успішність простої, одноманітної розумової діяльності залежить від сили нервової системи. $€$ повідомлення про зв'язок стійкості до одноманітності та властивостями темпераменту [8]. Виявлено залежно- сті зрушень функціонального стану випробуваних під час монотонної діяльності від вихідного балансу основних нервових процесів [9, 10]. Усі ці дані свідчать: продуктивність монотонної діяльності залежить від сукупності нейродинамічних і психодинамічних властивостей особистості. Водночас питання про те, які властивості організму людини забезпечують її стійкість до одноманітності, залишається відкритим [11, 12].

Метою дослідження було виявлення особливостей енергетичного забезпечення організму людини при здійсненні тривалої одноманітної роботи в осіб схильних та стійких до розвитку стану монотонії.

Матеріали та методи досліджень. Дослідження проводились на базі кафедри авіаційної, морської медицини і психофізіології Української військово-медичної академії і на базі ДУ «Інститут медицини праці НАМН». У дослідженнях брали участь добровольці, чоловіки та жінки, віком $(22 \pm 1,1)$ років (155 осіб). За допомогою спеціального комп'ютерного тесту випробувані піддавалися інформаційному монотонному навантаженню тривалістю 60 хвилин, що складалося з низки завдань [13]. Кожен логічний тест, що є елементом пропонованих для переробки завдань, мав
ОСОБЕННОСТИ ФУНКЦИОНИРОВАНИЯ

ЭНЕРГЕТИЧЕСКОЙ ПОДСИСТЕМЫ ОРГАНИЗМА ПО ПОКАЗАТЕЛЯМ ДЕЯТЕЛЬНОСТИ СЕРДЕЧНОСОСУДИСТОЙ СИСТЕМЫ У ЛИЦ СКЛОННЫХ И УСТОЙЧИВЫХ К РАЗВИТИЮ СОСТОЯНИЯ МОНОТОНИИ

Кальниш В.В., Пышнов Г.Ю.

Опанасенко В.В., Огрызков А.И.

ГУ «Институт медицины труда НАМН», Г. Киев

В связи с необходимостью управления сложными автоматизированными технологическими процессами проблема исследования состояния монотонии в операторской деятельности является достаточно актуальной на сегодняшний день.

Целью работы было выявление особенностей энергетического обеспечения организма человека при совершении длительной однообразной работы у лиц склонных и стойких к развитию состояния монотонии.

Материалы и методы. В исследованиях принимали участие 155 добровольцев, которые путем компьютерного тестирования подвергались информационной монотонной нагрузке, моде- лирующей операторскую деятельность.

Результаты. По показателям деятельности сердечно-сосудистой системы обследуемых выявлено, что энергообеспечение организма при выполнении однообразной работы у лиц, устойчивых и склонных к развитию состояния монотонии, происходит с помощью принципиально различных механизмов. У лиц, склонных к развитию состояния монотонии, изменения гемодинамики имеют выраженный фазный характер, что может свидетельствовать о дезадаптации и повышении физиологической стоимости работы при формировании состояния монотонии.

Выводы. Особенностью регуляции энергетического обеспечения однообразной деятельности у лиц, стойких к развитию монотонии, является гармоничность соотношения симпатического и парасимпатического отделов вегетативной нервной системы на фоне достаточно высокой активации ССС

Ключевые слова: монотония, однообразная работа, функциональное состояние, сердечно-сосудистая система, энергетическое обеспечение деятельности.

( Кальниш В.В., Пишнов Г.Ю., Опанасенко В.В., Огризков О.І. СТАТTЯ, 2016. 
тривалість 4,0 с, що (згідно 3 «Гігієнічною класифікацією праці ...» № ГН 3.3.5-3.3.8;6.6.1-0832001 р.) відповідає класу 3.2 за фактором «напруженість».

Вивчення стану вегетативної нервової системи здійснювалось відповідно до загальноприйнятих стандартів аналізу варіабельності серцевого ритму за допомогою апаратно-програмного комплексу, який був розроблений у Харківському національному університеті радіоелектроніки [14, 15]. Програма «ЕasyHRH» разом 3 реєстратором кардіоритму являють собою комплекс, призначений для дослідження стану серцево-судинної системи за показниками варіабельності серцевого ритму і параметрами T-хвилі PQRST-комплексу.

Аналіз ВСР проводився кожні 5 хвилин протягом виконання монотонної роботи (12 точок). Аналізувалися динаміка моди (Мо) кардіоінтервалів, її амплітуди (Amo), показника переваги активації парасимпатичного відділу регуляції CCC (pNN50) та співвідношення активності повільної і швидкої регуляції серцевим ритмом (LF/HF), що відображає рівень активності підкоркових симпатичних нервових центрів регуляції ССС [16].

Вивчення стану реактивності судин визначали за допомогою артеріографа Arteriograph «Tensiomed LTd» (Угорщина) [17, 18] кожні 5 хвилин експерименту. Аналізували динаміку таких показників гемодинаміки: систолічного артеріального тиску (САТ), діастолічного артеріального тиску (ДАТ), середнього тиску повного кардіоциклу (РРср), пульсового тиску (ПТ), середніх значень частоти серцевих скорочень (ЧСС), систолічного тиску в аорті (SBPao), пульсового тиску в аорті (Ррао), показника функції ендотелію в аорті (Aix Aor), тривалості періоду вигнання (ED).

За результатами тривалого виконання одноманітної роботи за показниками латентних періодів реакцій випробовуваних їх було поділено на дві групи. Представники I групи характеризувалися збільшенням реакцій у процесі дослідження і вважалися «схильними» до розвитку стану монотонії. Особи, яким було притаманне зменшення реакцій у процесі дослідження (II група), вважалися «стійкими» до розвитку стану монотонії [19]. Аналіз результатів проводився за допомогою методів варіацій-

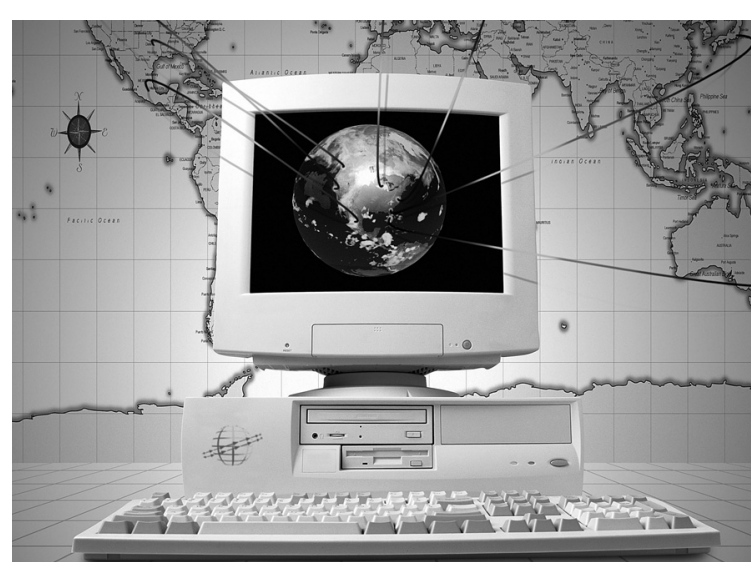

ФУНДАМЕНТАЛЬНІ ДОСЛІДЖЕННЯ

ної статистики, двофакторного дисперсійного аналізу з використанням пакета програм STATISTICA 6.1.478.0.

Результати досліджень та їх обговорення. Для виконання цього дослідження важливим був аналіз показників механічної активності серця і судин як показників, що відображають гемодинамічний статус людини, який віддзеркалює фундаментальні умови життєдіяльності організму.

Розглядаючи показники гемодинаміки, насамперед необхідно відзначити, що у більшості випадків ці показники достовірно відрізняються у групах осіб, стійких і схильних до розвитку стану монотонії. Але часова динаміка цих показників схожа або відрізняється лише тенденцією змін кожного 3 них. Причому різниця рівнів оцінюваних характеристик у виділених групах випробовуваних проявлялася з самого початку експерименту, а не була наслідком зміни функціонального стану

\section{Показники Рерифунок 1}

срійної гемодинаміки під час тривалого виконання одноманітної роботи. А - динаміка систолічного артеріального тиску (САТ); Б - динаміка діастолічного артеріального тиску (ДАТ); В - динаміка середнього тиску повного кардіоциклу; Г - динаміка пульсового тиску. $\rightarrow$ - стійкі до монотонії,
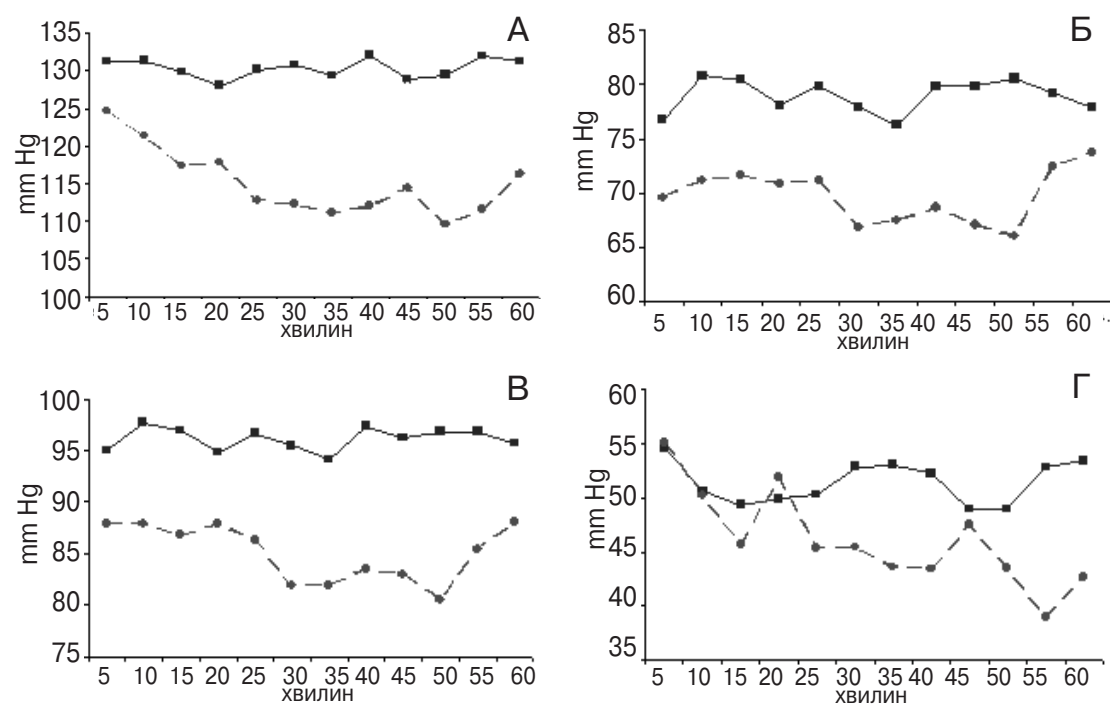
Порівнюючи відносну відсутність вираженої динаміки САТ в осіб стійких до розвитку стану монотонії і певну тенденцію до зниження рівня показника САТ в осіб схильних до розвитку монотонії (де рівень обговорюваного показника знижується з плином експерименту від 125 мм рт.ст. до 110 мм рт.ст.) можна констатувати, що представники першої групи постійно підтримують високий рівень своєї активації, а представники другої поступово знижують цей рівень.

Що стосується динаміки діастолічного артеріального тиску (ДАТ), залежного від ступеня прохідності або величини відтоку крови через систему прекапілярів, що зумовлена тонусом цих судин і пружнов'язкими властивостями артеріальних судин, то вона підтримується майже постійною протягом усього експерименту у представників обох груп (рис.1Б). Однак спостерігається істотна різниця у рівні цього показника $(p<0,05)$. У осіб стійких до розвитку стану монотонії ДАТ $\approx 80$ мм рт.ст., а у представників групи схильних до розвитку стану монотонії цей показник периферичного судинного опору має більш низький рівень і дорівнює $\approx 70$ мм рт.ст. Зазвичай обидва рівні вкладаються у рамки норми для випробовуваних молодого віку, які брали участь в експерименті. Однак більш низькі значення ДАТ можуть свідчити про стабільно менший тонус судин і менш виражену активацію ЦНС у
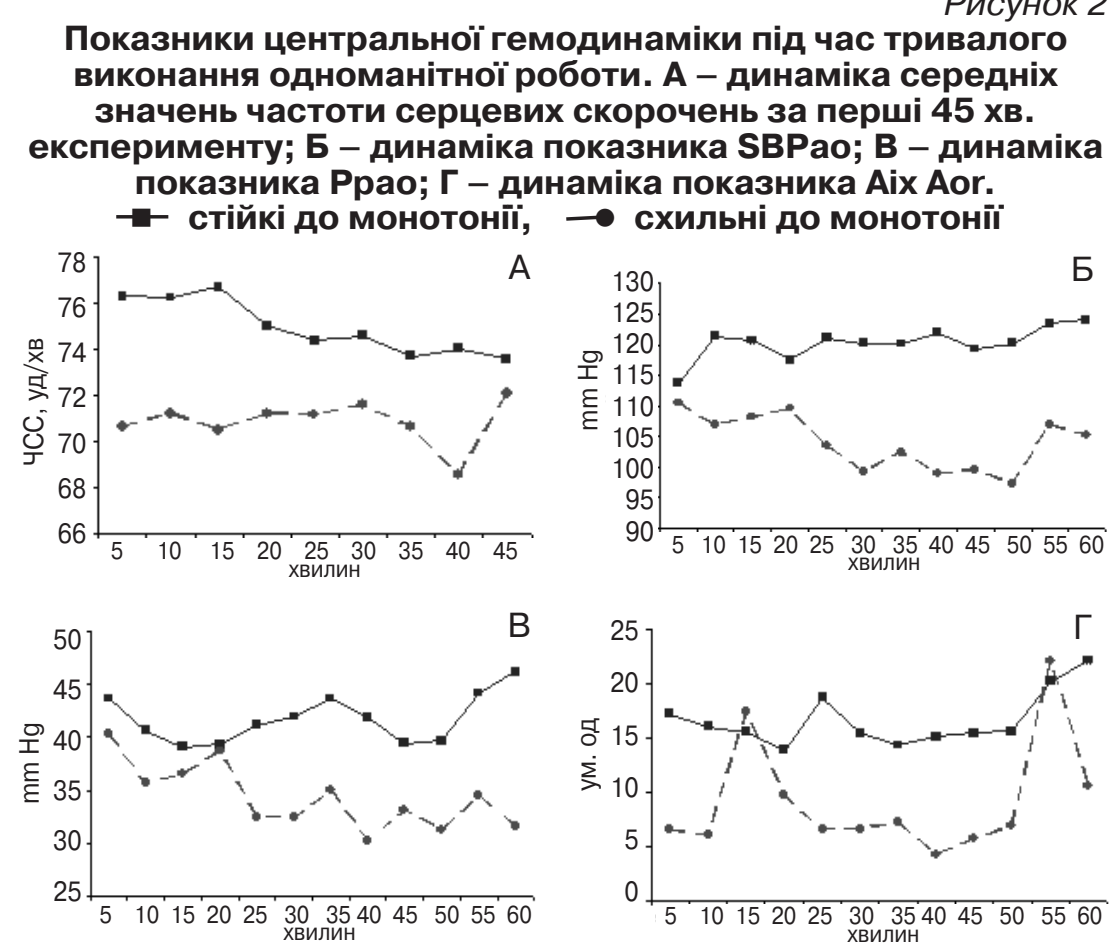

представників групи схильних до розвитку стану монотонії.

Ще одним фундаментальним показником гемодинаміки $\epsilon$ показник середнього тиску (Рср), динаміка якого представлена на рисунку 1В. Середній тиск відображає енергію безперервного руху крови [20]. Характерною для цього показника є відсутність впливу фактора часу протягом годинного експерименту. Однак його рівень в осіб стійких до розвитку монотонії коливається у діапазоні 94-97 мм рт.ст., а у представників групи схильних до розвитку цього стану - у діапазоні 80-88 мм рт.ст. Якщо залучити дані двофакторного дисперсійного аналізу, що вказують на достовірну різницю РРср у цих групах, то можна з упевненістю стверджувати, що енергія безперервного руху крови в осіб стійких до розвитку монотонії вища, отже активація їхнього організму більша, ніж у групи осіб схильних до розвитку стану монотонії $(p<0,05)$.

Щодо показника пульсового тиску (ПТ), то тут цікавим видається той факт, що значні відмінності $(p<0,05)$ у рівнях цього показника в обох групах проявляються лише у другій частині проведеного експерименту, тобто вже у той період, коли розвиток стану монотонії в осіб схильних до його формування вже відбувся або завершується (рис. 1Г). Мабуть, саме у цей період починають підключатися регуляторні ефекти функції

Рисунок 2

динаміки під час тривалого оти. А - динаміка середніх корочень за перші 45 хв.

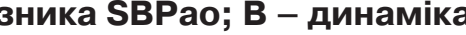
міка показника Aix Aor. $\longrightarrow$ схильні до монотонії

$\Gamma$

(1)

B' пакож можна позактивуванням організму випробовуваних, де люди стійкі до розвитку монотонії мають вищий рівень активації.

Дещо більш виражену фазність зміни функціонального стану можна спостерігати за показником пульсового тиску в аорті Pрао (рис. 2B). Тут на початково- 
FEATURES OF THE FUNCTIONING OF ORGANISM ENERGY SUBSYSTEM BY INDICATORS OF CARDIOVASCULAR SYSTEM AMONG INDIVIDYALS PRONE AND RESISTANT TO DEVELOPMENT OF THE MONOTONY STATE

Kalnysh V., Pyshnov G., Opanasenko V., Ogryzkov A. Institute for Occupational Health of the National Academy of Medical Sciences of Ukraine

In connection with the need to manage complex automated processes, the problem of study of the state of monotony in the operator's activity is quite actual today.

The goal was the revealing of features of the energy supply of the human body when making long-term monotonous work among individuals inclined and resistant to the development of the state of monotony. Materials and methods. In studies 155 volunteers took part, who were tested by monotonous information load modeling (by computer) operator activity.

Results. In indexes of the cardiovascular system activity it is revealed that the energy supply of the body during performing monotonous work among people resistant and prone to the development of the state of monotony is going by fundamentally different mechanisms. Individuals who are prone

to the development of the state of monotony,

hemodynamic changes have a pronounced phase character, what may indicate on the disadaptation and raise the physiological cost of work in the formation of the state of monotony.

Conclusions. A feature of the regulation of the energy supply of monotonous activity among individuals resistant to the development of monotony, is the harmonious relations of the sympathetic and parasympathetic divisions of the autonomic nervous system against the background of relatively high activation of cardiovascular system.

Keywords: monotony, monotonous work, functional state of cardiovascular system, energy supply of activity. му етапі експерименту, коли в осіб схильних до розвитку монотонії тільки формується цей стан, можна побачити однакову динаміку трансформації цього показника у представників обох досліджених груп. Надалі, коли стан монотонії вже сформувався, спостерігається значуще $(p<0,05)$ розшаровування аналізованих кривих. Причому рівень пульсового тиску в аорті в осіб схильних до розвитку монотонії стає набагато нижчим, ніж у представників групи стійких до розвитку стану монотонії. Ці результати не суперечать раніше висловленим припущенням про більшу активованість організму осіб стійких до монотонії, але підкреслюють той незаперечний Факт, що при формуванні стану монотонії здійснюються кардинальні зрушення у функціональному стані більшою мірою в осіб схильних до розвитку монотонії, ніж у стійких.

Цікава динаміка спостерігається за показниками функції ендотелію в аорті (Aix Aor). Тут відзначається виражена нестабільність рівня зазначених показників у процесі експерименту. Певні відмінності у «поведінці» цих показників, очевидно, зумовлені морфологічними особливостями структури аорти (яка практично не має м'язових волокон) і плечової артерії (де м'язові волокна присутні) і різною віддаленістю цих компонентів ССС від серця. Порівнюючи зміни показника Aix Aor у процесі експерименту, слід зазначити, що його коливання в осіб стійких до розвитку монотонії набагато менші, ніж у схильних до формування цього стану (рис. 2Г). Достовірність різниці дисперсій показників Aix Aor в осіб схильних та стійких до розвитку стану монотонії проявляється на рівні $\mathrm{p}<0,01$, що доведено за допомогою порівняння дисперсій цих показників за допомогою F-критерію Фішера. Крім того, двофакторний дисперсійний аналіз вказує на значущу дію чинника стійкості/схильності до розвитку стану монотонії на рівні $\mathrm{p}<0,05$.

Узагальнюючи дані динаміки показників Aix Aor, що оцінюють ендотеліальну функцію судин у представників обох груп, необхідно відзначити, що адаптація судинної системи здійснюється у них за допомогою різних механізмів. Якщо в осіб стійких до розвитку монотонії дещо «слабке» коливання цього показника свідчить про сталість їхнього функціонального стану, то адаптація до одноманітної діяльності у представників групи схильних до розвитку стану монотонії здійснюється менш раціональним способом - шляхом нестійкого «тремтіння» показника функції ендотелію. Подібна «поведінка» аналізованої функції може свідчити про підвищену чутливість механізмів, що її регулюють, а також про відсутність або менш виражену дію механізмів її гомеостазу в осіб схильних до розвитку стану монотонії. у цьому випадку, ймовірно, можна припустити, що фізіологічна вартість одноманітної роботи для осіб стійких до розвитку стану монотонії $\epsilon$ набагато нижчою, ніж у представників групи схильних до розвитку монотонії.

Особи молодого віку, які брали участь в експерименті, мали достатньо високі фізіологічні резерви організму і через це легко виконували запропоновану роботу. Тому деякі показники, зокрема тривалість періоду вигнання (ED), мали однакову тенденцію до зниження у процесі дослідження (рис. 3), що підтверджує результати двофакторного дисперсійного аналізу, на основі якого можна констатувати вплив фактора часу на рівні $p<0,05$. Динаміка цих функцій описує цілком природний процес зменшення тривалості вигнання при виконанні роботи, що не вимагає значних фізичних зусиль, ускладнену тривало підтримуваною вимушеною робочою позою (гіподинамія). У цьому механізми формування функціонального стану за показником ED повністю тотожні у представників обох груп.

Таким чином, дослідження функцій гемодинаміки в осіб схильних і стійких до розвитку стану монотонії при виконанні тривалої одноманітної роботи показало значну розбіжність в енергетичному забезпеченні діяльності представників цих груп. Необхідно констатувати, що розглянуті гемодинамічні показники в осіб стійких до розвитку монотонії були досить стабільними у процесі проведення експерименту і свідчили

Рисунок 3
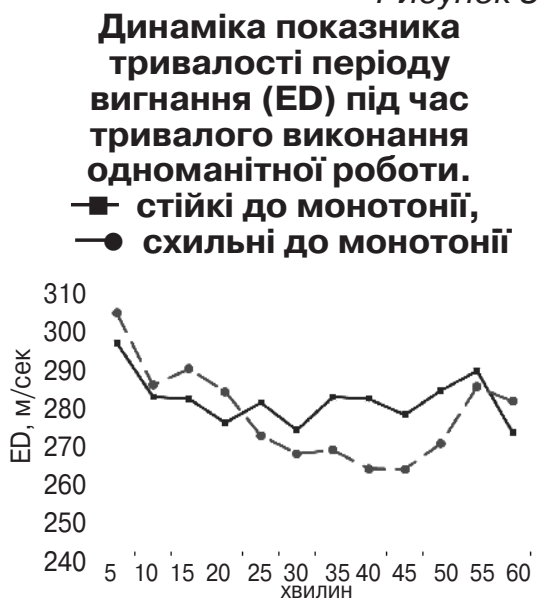
про наявність більш високої напруги функцій ССС у цій групі порівняно 3 представниками групи схильними до розвитку монотонії вже на самому початку дослідження, коли на функціональний стан досліджуваних ще не діяв фактор одноманітності виконуваних завдань. Проаналізовані показники гемодинаміки в осіб схильних до розвитку монотонії мали переважно фазний характер, особливістю якого були зміни у процесі розвитку стану монотонії (Ррао) у перші 30 хв. експерименту, монотонії (PWVao) у другій половині експерименту або нестійкістю за увесь період дослідження (Aix Brach). Цей феномен, ймовірно, можна трактувати як нестійкість функціонального стану - постійний пошук більш раціонального управління гемодинамікою організму, що веде до підвищення витрати функціональних резервів організму осіб схильних до розвитку монотонії.

Формування варіабельності серцевого ритму є результатом взаємодії різних підсистем багаторівневої ієрархічно організованої нелінійної системи управління серцево-судинною системою, що забезпечує енергетичний компонент, зокрема трудової діяльності. Тому аналіз різних параметрів серцевого ритму може дати додаткову цінну інформацію про механізми житвже після формування стану

тєдіяльності осіб схильних або стійких до розвитку стану монотонії у процесі виконання ними одноманітної роботи.

Ймовірно, розгляд цих характеристик слід почати з показника, що відображає найімовірніший рівень функціонування ССС Мо (мода RR інтервалів), динаміка якого для груп осіб схильних і стійких до розвитку стану монотонії представлена на рисунку 4А. Навіть попередній аналіз цього показника переконує, що рівень функціонування ССС в осіб схильних і стійких до монотонії різко відрізняється. Про вірність цього висновку свідчить проведений двохфакторний аналіз, де доводиться, що дія чинника стійкості/схильності до розвитку стану монотонії перебуває на високому рівні $(p<0,01)$. На наведеному рисунку можна помітити, що в осіб стійких до розвитку стану монотонії RR-інтервали є значимо коротшими протягом експерименту з одноманітним розумовим навантаженням.

Додаткові відомості про відносну активність симпато-парасимпатичної регуляції функціонування СCC дає показник LF/HF, динаміку якого представлено на рисунку 4Б. Тут чітко видно, що зміни симпато-парасимпатичного балансу мають нелінійний характер. Причому дія фактора схильності/стійкості до розвитку стану монотонії проявляється досить яскраво на

Рисунок 4

Показники варіабельності серцевого ритму при тривалому виконанні одноманітної роботи. А - динаміка моди кардіоінтервалів (Мо), за перші 45 хв. експерименту; Б - динаміка значень рівня активності підкоркових симпатичних нервових центрів регуляції (LF/HF);

B - динаміка амплітуди моди (AMо, \%); Г - динаміка рівня переваги парасимпатичного відділу регуляції (рNN50, \%). - стійкі до монотонії,
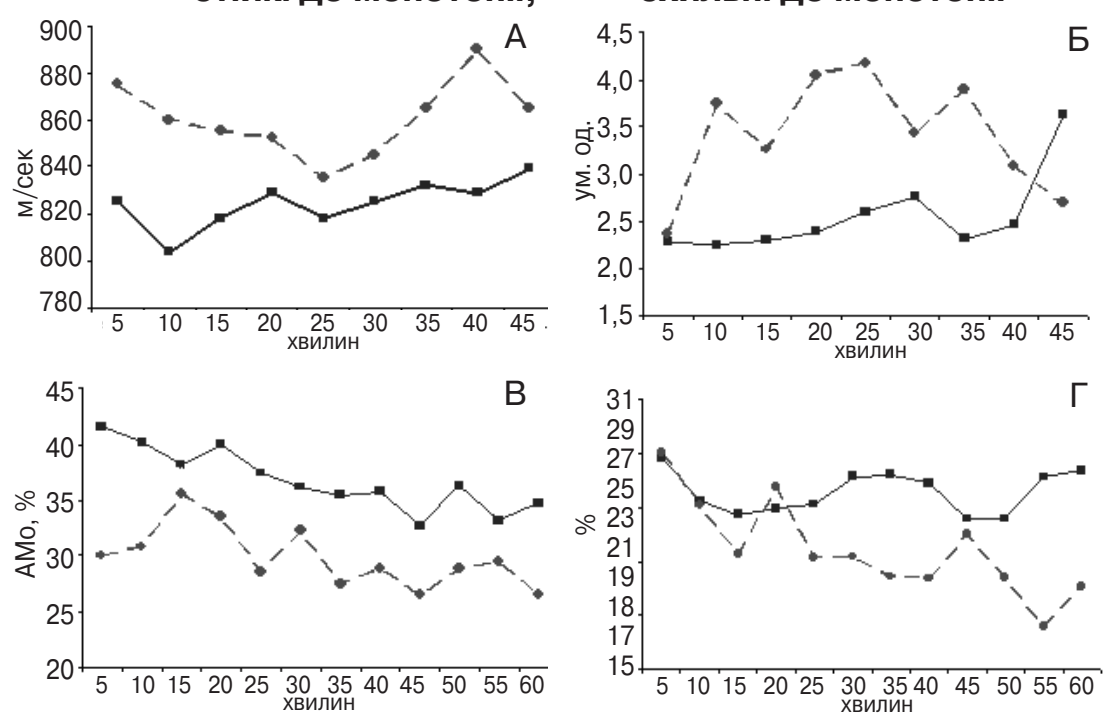

рівні $p<0,01$. Цікавим $€$ той факт, що у початковій стадії експерименту, коли стан монотонії в осіб схильних до розвитку цієї ситуації рівень показника LF/HF однаковий для представників обох досліджуваних груп і перебуває у межах популяційної норми. Наприкінці експерименту, коли стан монотонії в осіб схильних до розвитку цієї ситуації вже сформувався, рівні характеристики LF/HF знову стають однаковими для представників обох груп випробовуваних, але вже дещо перевищують межі нормативних популяційних значень.

Загалом у ході дослідження рівень показника LF/HF переважно значно нижчий у групи осіб стійких до розвитку монотонії, що говорить про гармонійність активації симпатичного і парасимпатичного відділів вегетативної нервової системи в організмі цих людей. Більш високий рівень показника LF/HF спостерігається у представників групи схильних до розвитку монотонії. У середині експерименту, коли у них інтенсивно формується стан монотонії, рівень показника LF/HF доходить до 4 ум. од., що може підтвердити припущення про стійке порушення симпато-парасимпатичного балансу у регуляції функціонування ССС у цих досліджуваних у бік переважання активації симпатичного відділу вегетативної нервової системи.

Ще один важливий результат слід підкреслити у цьому дослідженні. За показником АМо (рис. 4В) рівень активації симпатичної системи у представників групи стійких до розвитку монотонії $€$ вищим, ніж в осіб схильних до розвитку монотонії. А за показником pNN50 (міра переваги активації парасимпатичного відділу регуляції) - нижчим (рис. 4Г). Але у результаті ці трансформації окремих складових регуляції ССС призводять до «нормативного» балансу активності симпатичної і парасимпатичної систем в організмі представників групи стійких до монотонії за показником LF/HF. Однак при цьому ступінь напруги регуляції серцевого ритму у представників цієї групи значно вищий, ніж в осіб схильних до розвитку монотонії. Описаний феномен, який окреслює, здавалося б, суперечливі твердження, можна подолати, враховуючи той факт, що у розглянутих групах людей схильних або стійких до розвитку стану монотонії 
існують у чомусь різні механізми формування відповідного рівня функціонального стану. У стійких до розвитку стану монотонії спостерігається більш висока напруга регуляції серцевого ритму, але вона якоюсь мірою компенсується наявністю стійкого симпато-парасимпатичного балансу вегетативної нервової системи. А в осіб схильних до розвитку монотонії зниження рівня активації організму призводить до підвищення парасимпатичного і зниження симпатичного тонусу, що відбуваються на тлі значного порушення гармонізації функціонування вегетативної нервової системи. Мабуть, зниження активації організму у схильних до монотонії осіб компенсується за рахунок значного порушення цього балансу, особливо у період інтенсивного становлення стану монотонії.

Таким чином, енергетичне забезпечення однорідної роботи в осіб стійких і схильних до розвитку стану монотонії відбувається різними шляхами. При цьому порушується нормальна діяльність окремих ланок системи забезпечення регуляції ритму серця і гемодинаміки загалом.

\section{Висновки}

1. Енергетичне забезпечення однорідної роботи у стійких і схильних до розвитку стану монотонії осіб відбувається за допомогою суттєво різних механізмів, про що свідчить наявність досить різного рівня багатьох характеристик СCC ще до початку виконання тривалої одноманітної роботи.

2. У осіб схильних та стійких до розвитку стану монотонії є значна розбіжність у гемодинаміці, яка забезпечує енергетичні витрати у процесі виконання одноманітної діяльності $(p<0,05)$. У осіб стійких до розвитку стану монотонії показники гемодинаміки достатньо стабільні у процесі роботи, але характеризуються вищими значеннями тонусу судин, що свідчить про високу готовність їхнього організму до результативного її виконання. у осіб схильних до розвитку стану монотонії зміни гемодинаміки мають фазний характер, який можна трактувати як нестійкість функціонального стану, що супроводжується постійним пошуком шляхів адаптації до одноманітної діяльності та веде до пришвидшеного зниження функціональних резервів організму.
3. Особливістю регуляції енергетичного забезпечення одноманітної діяльності у стійких до розвитку стану монотонії осіб $€$ гармонійність співвідношення активності симпатичного і парасимпатичного відділів вегетативної нервової системи (LF/HF) на тлі достатньо високої активації серцево-судинної системи (за показником ЧСС). Низький рівень активації серцево-судинної системи в осіб схильних до розвитку стану монотонії компенсується за рахунок нестійкості та постійного порушення симпато-парасимпатичного балансу (LF/HF) у бік переважної активації симпатичного відділу вегетативної нервової системи, що свідчить про низьку адаптаційну спроможність організму у представників цієї групи до виконання одноманітної роботи.

ЛІТЕРАТУРА

1. Сопов В.Ф. Психические состояния в напряженной профессиональной деятельности / В.Ф. Сопов. - М.: Акаде-

мический проект, 2005. - 128 с.

2. Патырбаева К.В.

Формирование НФОТ как условие прогрессивного развития и метод формирования человеческого потенциала / К.В. Патырбаева // Современное общество: вопросы теории, методологии, методы социальных исследований. - Пермь: издательство ПГТУ, 2006. - С. 87-89.

3. Gozhenko A.I. Conditions and ways of reforming of marine medicine in Ukraine / A.I. Gozhenko // 11-th International Symposium on Maritime Health. 06-10 of September, Odessa, Ukraine. Book of Abstracts. Odessa, 2011. - 44 p.

4. Бодров В.А.. Психология и надежность. Человек в системе управления техникой / В.А. Бодров, В.Я. Орлов // Институт управления $\mathrm{PAH}, 1998 .-186 \mathrm{c.}$

5. Wilson G.F. Operator functional state classification using multiple psycho physiological features in an air traffic control task / G.F. Wilson, C.A. Russell // Human Factors. - 2003. - V. 45, № 3. P. 381-389.

6. Кукин П.П. Безопасность жизнедеятельности. Безопасность технологических процессов и производств (Охрана труда): Учебное пособие для вузов / П.П. Кукин, В.Л. Лапин, Е.А. Подгорных и др. - 4-е изд., перераб. - М.: Высш. шк., 2007. - 61 с.

7. Рождественская В.И. Индивидуальные различия работоспособности (психофизиологическое исследование работоспособности в условиях монотонной деятельности) /
В.И. Рождественская. - М.: Педагогика, 1980. - 151 с.

8. Аминов Н.А. Индивидуальные различия в динамике функциональных состояний при однообразной работе /

Н.А. Аминов. // В сб.: Проблемы дифференциальной психофизиологии. - М.: Педагогика, 1977. - Т. 9. - С. 108-120.

9. Бушов Ю.В. Связь индивидуальных свойств человека-оператора с продуктивностью деятельности и устойчивостью к влиянию фактора монотонности труда / Ю.В. Бушов, Ю.А. Рябчук // Вопросы психологии. - 1981. - № 1. - С. 126-130.

10. Кирой В.Н. Индивидуальная устойчивость К действию факторов монотонии и ее отражение в ЭЭГ / В.Н. Кирой,

Е.В. Асланян // Журнал высшей нервной деятельности

им. И.П. Павлова. - М., 2006. T. 56, № 1. - С. 38-46.

11. Городецкий И.Г. Разработка адаптивной автоматизированной системы, моделирующей совмещенную деятельность человека-оператора и позволяющей определить его индивидуальные психофизиологические особенности // И.Г. Городецкий, А.А. Скоморохов,

И.А. Артемов, Е.С. Захаров // Проблемы психологии и эргономики. - 2003. - № 3. - 24 с.

12. Берестнева О.Г.

Моделирование адаптационных стратегий человека-оператора / О.Г. Берестнева, К.А. Шаропин // Известия Южного федерального университета. Технические науки. - 2004. - Т. 41, № 6. - С. 3-7.

13. Агафонов А. Изучение Струп-феномена при усложнении задачи игнорирования / А. Агафонов, А. Федотова // Психологические исследования. Сб. науч. тр. - Самара : Изд-во «Универс-групп», 2005.

- C. 28-35.

14. Кочина М.Л. Компьютерный ритмограф / М.Л. Кочина, А.А. Каминский // Радиотехника. - 2010. - № 160. - C. 263-267.

15. Кочина М.Л. Информационная технология прогноза функционального состояния сердечно-сосудистой системы / М.Л. Кочина, А.А. Каминский, В.А. Маленкин // Кибернетика и вычислительная техника. - 2012. - № 170. - С. 15-27.

16. Анализ вариабельности сердечного ритма при использовании различных электрокардиографических систем: метод. рек. / Р.М. Баевский и соавт. M., 2002. - 53 c.

17. Baulmann J. A new oscillometric method for assessment of arterial stiffeness: comparison with 
tonometric and piezo-electronic methods / J. Baulmann,

U. Shillings, S. Rickert et al. // J. Hypertension. - 2008. - № 26. - P. 523-528.

18. Horvath I.G. Invasive validation of a new oscillometric device (Arteriograph) for measuring augmentation index, central blood pressure and aortic pulse wave velocity / I.G. Horvath, A. Nemeth, Z. Lenkey et al. // J. Hypertension. - № 28, P. 2068-2075

19. Кальниш В.В. Характеристика динамики реакций лиц склонных и устойчивых к развитию состояния монотонии при операторской деятельности // В.В. Кальниш, Г.Ю. Пышнов, А.В. Мальцев, Е.В. Красотин // Актуальные проблемы транспортной медицины. - 2014. № 4, T. 1 (38-I). - C. 104-114.

20. Инструментальные методы исследования сердечнососудистой системы

(Справочник) / Под ред.

Т.С. Виноградовой. - М.

Медицина, 1986. - 416 с.

REFERENCES

1. Sopov V. Psihicheskie sostoyaniya v napryazhennoj professional'noj deyatel'nosti [Mental states during hard professional work]. M.: Academic Project; 2005: 128 p. (In Russian).

2. Patyrbaeva K. Formirovanie NFOT kak uslovie progressivnogo razvitiya i metod formirovaniya chelovecheskogo potenciala. Sovremennoe obshchestvo: voprosy teorii, metodologii, metody social'nyh issledovanij [Formation of the NFOT (TPLF) as a condition for the progressive development and the method of forming human potential. Modern society: theory, methodology, methods of social research]. Perm: Publishing Perm State Technical University; 2006: 87-89. (in Russian).

3. Gozhenko A. Conditions and ways of reforming of marine medicine in Ukraine. 11-th International Symposium on Maritime Health. 06-10 of September, Odessa, Ukraine. Conditions and ways of reforming of marine medicine in Ukraine. Book of Abstracts. Odessa; 2011:44.

4. Bodrov V., Orlov V. Psychologiya i nadjognost. Chelovek v systeme upravleniya technikoy. [Psychology and reliability. The man in the control system technics] Institute of Management RAS; 1998; 186. (in Russian).

5. Wilson G.F., Russell C.A Operator functional state classification using multiple psycho physiological features in an air traffic control task. Human Factors; 2003, 45(3):381-389.

6. Kukin P., Lapin V., Podgorny $E$. at al. Bezopasnost' zhiznedeyatel'nosti. Bezopasnost' tekhnologicheskih processov i proizvodstv (Ohrana truda): Uchebnoe posobie dlya vuzov [Health and Safety. Safety of technological processes and productions (Occupational Health): A manual for schools]. M.: Higher school; 2007:61 p. (in Russian).

7. Rozhdestvenskaya V. Individual'nye razlichiya rabotosposobnosti (psihofiziologicheskoe issledovanie rabotosposobnosti v usloviyah monotonnoj deyatel'nosti [Individual differences in performance (psychophysiological research performance in a monotonous activity)]. M.: «Pedagogy»; 1980:151 p. (in Russian).

8. Aminov N. Individual'nye razlichiya $v$ dinamike funkcional'nyh sostoyanij pri odnoobraznoj rabote [Individual differences in the dynamics of functional states with monotonous work]. In Coll.: Problems of differential psychophysiology,

Education; 1977, 9:108-120. (in Russian).

9. Bushov Yu., Ryabchuk Yu. Svyaz' individual'nyh svojstv cheloveka-operatora s produktivnost'yu deyatel'nosti i ustojchivost'yu $k$ vliyaniyu faktora monotonnosti truda [Connection of individual properties of the human-operator with performance activity and resistance to the influence of the labor factor monotony]. Questions of psychology; 1981, 1:126-130.

(in Russian).

10. Kiroy V., Aslanian E. Individual'naya ustojchivost'

$\mathrm{k}$ dejstviyu faktorov monotonii i eyo otrazhenie v EEG [Individual resistance to monotony factor and its reflection in the EEG]. Journal of Higher Nervous Activity behalf I.P. Pavlov; M.: 2006, 56(1): 38-46. (in Russian).

11. Gorodetsky l., Skomorokhov A., Artemov I., Zakharov E. Razrabotka adaptivnoj avtomatizirovannoj sistemy, modeliruyushchej sovmeshchennuyu deyatel'nost' cheloveka-operatora i

pozvolyayushchej opredelit' ego individual'nye psihofiziologicheskie osobennosti [Development of an adaptive automated system of modeling the combined activity of the human-operator, allowing to determine his individual physiological characteristics]. Problems of psychology and ergonomics; 2003, 3:24. (in Russian).

12. Berestneva O., Sharopin K. Modelirovanie adaptacionnyh strategii cheloveka-operatora [Modeling of adaptive strategies of the human-operator] Southern Federal University. Engineering; 2004, 41(6):3-7. (in Russian).

13. Agafonov A., Fedotova A Izuchenie Strup-fenomena pri uslozhnenii zadachi ignorirovaniya [Study of Stroop-phenomenon at complication of the task of ignoring]. Psychological research. Coll. scientific papers. Samara

Publishing house «Univers Group»; 2005:28-35. (in Russian).

14. Cochina M., Kaminsky A.

Komp'yuternyj ritmograf [Computer rhythmograph]. Radio engineering; 2010, 160:263-267. (in Ukrainian).

15. Cochina M., Kaminsky A., Malenkin $V$. Informacionnaya tekhnologiya prognoza funkcional'nogo sostoyaniya serdechno-sosudistoj sistemy [Information technology prediction of the functional state of the cardiovascular system].Cybernetics and Computer Science; 2012, 170:15-27. (in Ukrainian).

16. Analiz variabel'nosti serdechnogo ritma pri ispol'zovanii razlichnyh ehlektrokardiograficheskih sistem: metod. rekomendacii [The analysis of heart rate variability using different electrocardiographic systems: guidelines. Baevsky R. et al.]. M., 2002:53 p. (in Russian).

17. Baulmann J., Shillings U., Rickert S. et al. A new oscillometric method for assessment of arterial stiffeness: comparison with tonometric and piezo-electronic methods. J. Hypertension; 2008, 26:523-528.

18. Horvath I., Nemeth A., Lenkey $Z$. et al. Invasive validation of a new oscillometric device (Arteriograph) for measuring augmentation index, central blood pressure and aortic pulse wave velocity. J. Hypertension; 2010, 28:2068-2075.

19. Kalnish V., Pyshnov G., Maltsev A., Krasotin E.

Harakteristika dinamiki reakcij lic sklonnyh i ustojchivyh k razvitiyu sostoyaniya monotonii pri operatorskoj deyatel'nosti

[The Feature of dynamics of reactions of individuals prone and resistant to the development of the state of monotony during the operator's activity].

Actual problems of transport medicine; 2014, 4(1):104-114.

(in Ukrainian).

20. Instrumental'nye metody issledovaniya serdechno-sosudistoj sistemy (Spravochnik) [Instrumental methods of research of the cardiovascular system (Manual). Ed. Vinogradova T.]. M.: Medicine; 1986:416 p

(In Russian).

Надійшло до редакції 16.08.2016 